Forest Products Laboratory, $\underline{1}$ Forest Service

U. S. Departrient of igriculture

1951

\title{
A YODIR
}

\author{
Turraeanthus africana (Trelr.) Pellegrin \\ (= Guarea africana Wel\%. = Binceria africana $\mathrm{A}$. Chev.) \\ Family: Feliaceae
}

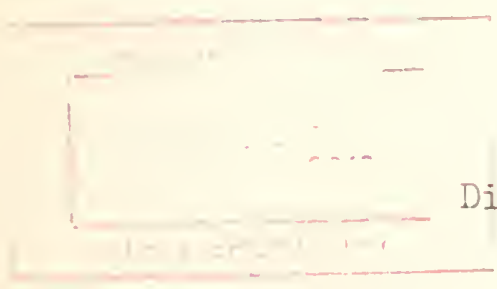

Avodiré (Turraeanthus africana (Welv.) Pellegrin) is a species from tropical Viest if rica that has recently become of considerable comercial importance on European and imerican rardrood markets. The species was first described in 1878 by Dr. Welvitch as Cuarea africana (C. DC.) from ingola, Test ifrica. In $1909, \mathrm{~A}$. Chevalier described and named it as ingeria africana $\mathrm{A}$. Chev., but 2 years later Fellegrin referred the species to tire genus Turraeantrus, and the recognized scientific name is now Iurraentrus africana (".cli) KII. It is a member of the lieliaceae family $(20,22,25)$, w wich includes some of the best knorn cabinet woods, such as iahogany (Srietenia spp.), ifrican mahogany (Khaya spp.), Spanish cedar, and andiroba (ㅁ).

Avodiré is manufactured in the same manner as fifrican mahozany, and when stained and finished, the rood is difficult to distingush from African mahogany, although the trees do not look alike externaliy (22). It las been offered for sale as white mahogany, African mahogany, African satinrood, and African furniture wood (14). The principal handicaps to its extensive use are its comparatively small size and limited occurrence, tie poor shape of the logs, and the tendency of fresliy cut timber to stain if not carefully handled (29). Althourh the rood has come on the market only comparatively recently, its popular blond color, low price, beautiful ficure, and easyvorking qualities have created a considerable demand (ó).

Tiaintained at Madison, Wis., in cooperation with the triversity of "isconsin. $\underline{2}$

Underlined numbers in parentheses refer to the Iist of numbered references at the end of the article. 
Avodire is the generally accepted trade name for Turraeanthus africana. It has the advantage of not conflicting with that of any other commercial rood on the American market. Whether this name is a combination of various native names or one given by the French is not knovm. The name "white mahogany" has also been used, because the rood is much like that of African mahogany except for its color, which is pale tan approaching white (22). Other names are:

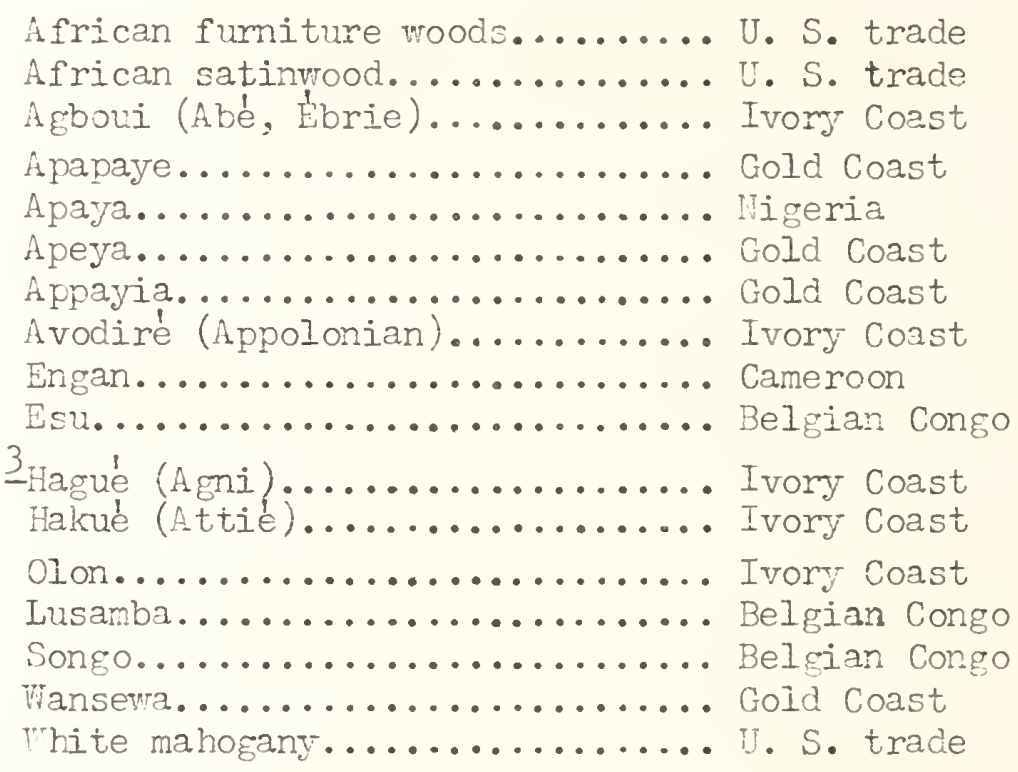

Distribution and Habitat

Avodiré occurs as an understory tree in the rain forests of parts of tropical West Africa, including the Gold Coast, Ivory Coast, and Angola, but is essentially an Ivory Coast species. The trees are not uniformly distributed in the rain forests, but are often localized in almost pure groups (1). Avodiré is reported as abundant in the region of the east Ivory Coast from the Agneby River on the west to the Bia River on the east. Avodiré and other species of Turraeanthus are also said to gron in the Cold Coast, Nigeria, the Cameroons, Cabon, Liberia, and the Belgiar. Congo, although they are not as comon in these regions, and there is little information on the occurrence (I) or on the wood of some of these species.

Avodire is probably typical of the genus (29). According to Dr. Velwitch, avodire is not a coastal or low-altitude species but attains its best development in the foothills 50 to 100 miles inland in the upland forests. It does

${ }^{3}$ Name applied also to the Bossé wood (Guarea cedrata Pell.), which possesses different characteristics (ㅁ) . 
not Erow, however, above the 2,500-foot contour line where concitions grade into the highland-forest type. It occurs in rich, moist soil on tie borders of streams and the marcins of neador's, swamps, and lakes (22).

\section{The Tree}

Size and Form

Avodiré is a medium-sizec tree in comparison to the giants of rest Africa. It mar reach 60 to 100 feet in reight but attains 90 feet or more only urcer favorable conditions (1, 29). It often las a ciiametcr at the base of 3 to 4 feet, even up to 5 feet. Generally, the tree is of poor habit of growth. The trees do not develop very clear or straight trunks, wich resul's in considerable vaste in logging (22). The utilizable part of the bole is usually from 25 to 50 feet in length, rarely more than 65 feet (7). Therefore, a lare percentare of the rood has to be rejected in the forest as unfit for exrort. A small percentage of the choicest material yielc's figured wood suitable for fine veneer (6). The stems very often divide into vide spreading branches and form large croms (22). Dr. Welwitch is quoted (22) as describing Turraeantlus africana as "an immense, handsome tree" in his monograpt on the flora of tropical ffrica.

\section{The Bark}

The bark is ash-colored, tinged with red, and stands out in contrast with the very dark, glossy green of the foliage (22). The bark is said to have toxic properties ( 1 ). It peels off in thin strips, the inner portion being creamy yellow and possessing a very characteristic aromatic odor (29). In order to prevent fungus damage, it is necessary to remove the bark to help the wool dry out promptly; consequently, the loes entering the mariset are invariably free of $\operatorname{bark}(\underline{6})$.

\section{Leaves}

The compound leaves are large (2 feet or more in leneth), and are composed of 4 to 12 pairs of alternate, oblong leaflets, 4 to 6 inches lons, about $1-1 / 2$ inches wide, and rounded at the apex. The leaflets are smooth, shiny, and leathery. The midrib is very prominent on the upper surface and has many fine lateral nerves. The leaf buds, roung petioles, and florer stalks are covered with a fine, rusty pubescence (29). The leaves are crowded at the ends of the branches and this give the tree an unusual arpearance (22).

\section{Flowers and Fruit}

The white to creamy-yellow flowers are in clusters in the axils of the leaves and form very conspicuous panicles that have numerous flowers. The flowers differ very little from those of mahogany. They may be found nearly all the 
year round, although the main flovering period is in the spring, with a second, though less abundant blossoming in the autumn $(\underline{1}, \underline{22})$.

The fruit takes about 6 months to develop and generally matures in the autumn. It is in the form of a fig-shaped, fleshy capsule. These capsules are over an inch in diameter, yellow or orange in color, scented, and have a soft, whitish pulp in which the seeds (usually 4 or 5 in number) are imbedded. The seeds geminate readily, and the young seedlings are plentiful, although few survive in the dense shade of the old-grouth forests. They quickly fill up any openings in the stand and are easily transplanted ( 1,29 ).

The Wood

General Appearance

Although avodire belongs to the Meliaceae family, the wood has few characteristics of mahogany. When stained and finished, however, the figured wood may greatly resemble African mahogany superficially (22). Its natural pale color and high, satiny luster have occasioned the use of the wood as a substitute for satinwood (6). The logs vary greatly in color, grain, figure, and quality (14). The crooked, irregular logs often contain ring checks and even cross or wind breaks (22).

Color

The rood is creamy white to pale yellow, sometimes darkening to golden yellow (19). Unlike most of the lieliaceae, the color is light and uniform throuchout. Since the heartwood is not distinctly colored, it is difficult to distinguish the sapwood from the heartwood areas; the wood is therefore easy to match in use and is especially valued for use where blond rood is desired $(\underline{6}, \underline{2} 4)$.

Luster

When worked, the vood has a high, satiny, natural luster (1, 18).

Weicht

The vood is rather light to heavy in weicht and soft to moderately hard; specific gravity 0.45 to 0.60 (air-dry), which is in the mahogany range; veight usually about 31 to 37 pounds per cubic foot (18, 26). It is fairly resistant to indentation (29). Avodiré proved less kârd than most of the cabinet roods tested by Harrar (10). The results given in table 1 are taken from his tests. 
Table 1.--Results of tests of hardness on cabinet woods

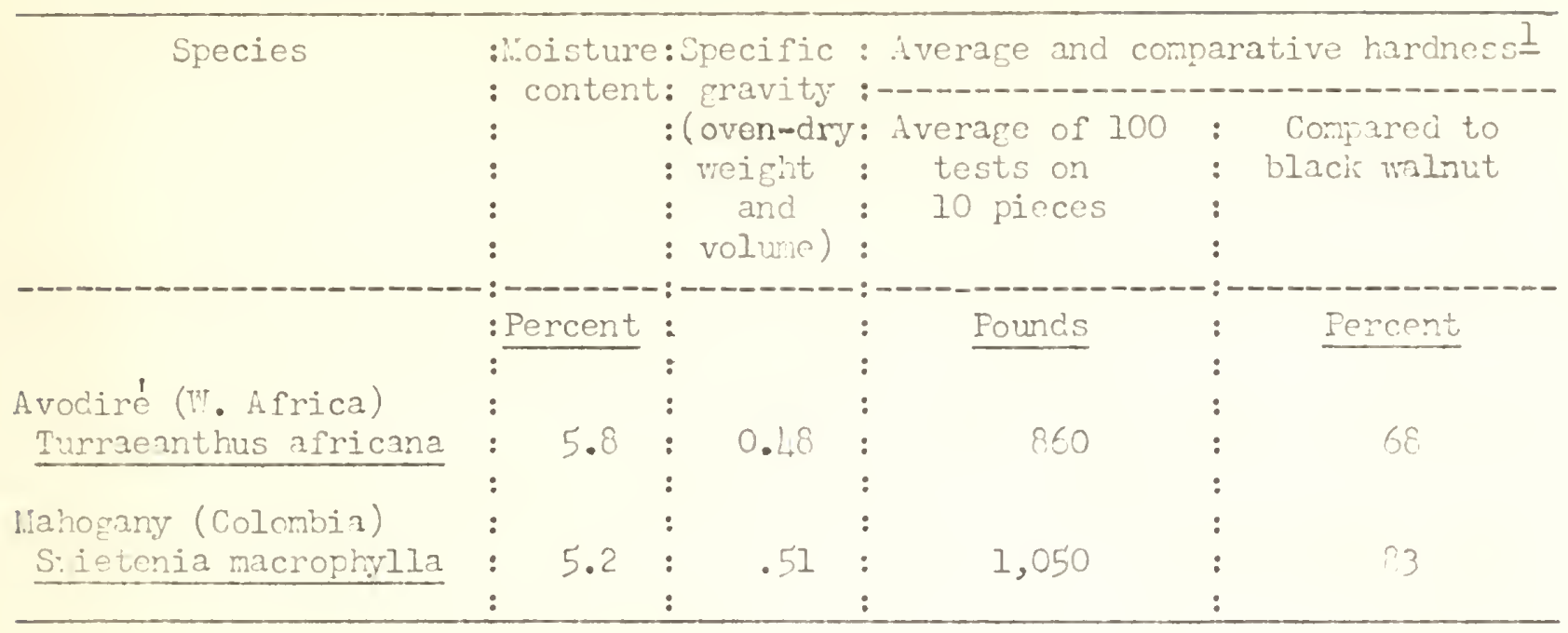

I Load required to embed a $0.444-$ inch bail to one-ralf its ciameter.

Grain, Texture, and Figure

The erain may be straicht but is frequently wavy or interlocked, which produces a mottled figure on quarter-cut material. The texture is fine and ufirm (I6). The irregular grain combined with the rish luster maj oive a fine noire

appearance to the finisred surface, wirh at itus best sugcests fimural satin wood (I). The ficured vooci may show considerable variety, such as strime, curl, or mottle (22).

Odor and Taste

Odor and taste are absent or not distinctive (29).

Mecharical Properties

The irformation on the mechanical properties of avocire is moager, but it is reputed to be a strong, tough, elastic timker in proportion to its veight (1, 14,16$)$. The follorine comparison of Vest ifrican species is taken from an article by honnin and collardet quoted in Veltholzwirtsciaft, "Jbersee Hollzer Beilace lir. 16, April 1950 (31). 


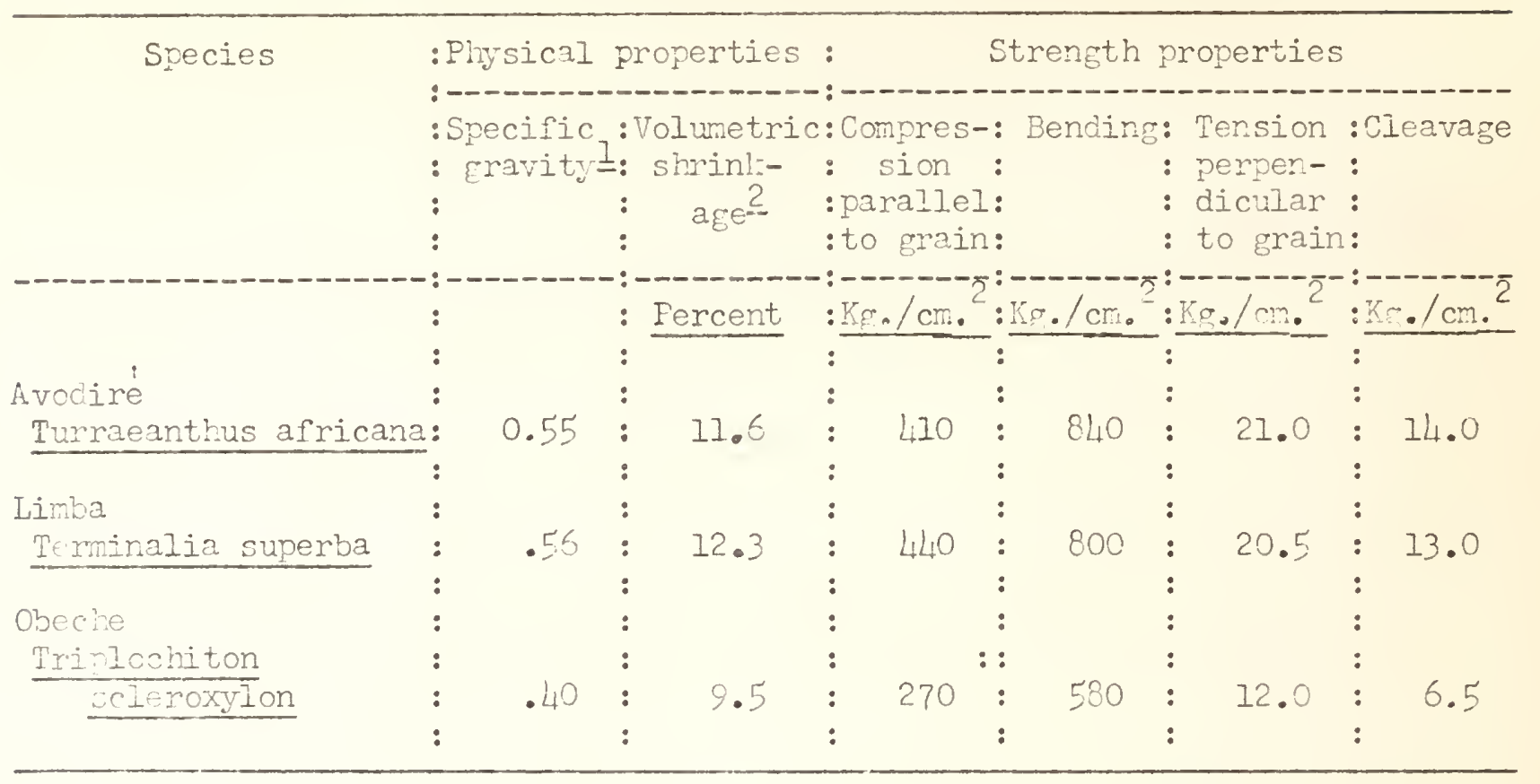

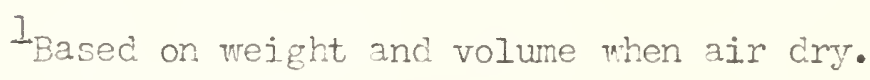

2 Based on green volume.

\section{Durability}

Because avodire is subject to decay and insect attack, loss should be converted into lumber as soon as possible after felling, unless storage in fresh water is provided (7). The mood should not be used in damp situations and is not durable in contact with the ground or in exposed situations (16, 22).

\section{Seasoning}

Avodire is reported to season readily, but care is needed to avoid splitting, and warping (16). From tests by Harrar (12), the percent of shrinkage of avodire is compared in table 3 to that of some of the cabinet woods with which it competes. 

Table 3.-Percent directional and volume shrinkare from green to oven-dry

\begin{tabular}{|c|c|c|c|c|c|c|c|c|}
\hline \multirow[t]{2}{*}{ Species } & : & \multicolumn{7}{|c|}{ Shrinkage } \\
\hline & \multicolumn{8}{|c|}{ : Lonfitudinal : Radial : Tancertial : Volum tric } \\
\hline \multirow{4}{*}{$\begin{array}{l}\text { Avodire (H: Africa) } \\
\text { Turrieanthus ifricana }\end{array}$} & : & $1+1 \therefore e n t$ & : & Percen & $:$ & Percoist & : & Perecrt \\
\hline & : & & : & & : & & : & \\
\hline & : & & : & & : & & : & \\
\hline & : & 0.24 & : & 4.03 & : & 6.19 & : & $=10$. \\
\hline \multirow{4}{*}{$\begin{array}{l}\text { Wahogany, African } \\
\text { Khuya iverensis }\end{array}$} & : & & : & & : & & : & \\
\hline & : & & : & & : & & : & \\
\hline & : & .28 & : & 4.96 & : & 8.36 & : & 16.88 \\
\hline & : & & : & & : & & : & \\
\hline \multirow{3}{*}{$\begin{array}{l}\text { Naho eny, Colombian } \\
\text { Swietenia macrop'yla }\end{array}$} & : & & : & & $:$ & & : & \\
\hline & : & .18 & : & 2.46 & : & 3.80 & : & 6.53 \\
\hline & : & & : & & : & & : & \\
\hline \multirow{3}{*}{$\begin{array}{l}\text { Satin rood, Ceylon } \\
\text { Chloropicra swietenia }\end{array}$} & : & & : & & : & & : & \\
\hline & : & .12 & : & 5.71 & : & 8.51 & : & $\mathrm{IL}_{4} .91$ \\
\hline & : & & : & & $:$ & & : & \\
\hline
\end{tabular}

Liompare with value in table 2 .

Eorking Characteristics

Straight-erained wood is quite easy to work, but care is requirec in planing either quartered boards showing stripe figure or curly- or wavy-rined material to avoid surface tearing (I). A small cutting angle is desirable for a clean finish. Avodiré makes excellent veneer, especially sliced vereer, and has fairly good nailing, screw-holding, and gluing properties. It will take an excelient finish and can be stained evenly, although because of the present popularity of its light, natural color, this is not generally desired (16). The surface can be filled and holds filler well (22). In Harrains testis (II) on the screw-holding po"er of cabinet woods, avodire showed lower values than the three otter roods cited in table 4 . 
Table 4.--Screw-holding power of cabinet woods

\begin{tabular}{|c|c|}
\hline \multirow[t]{4}{*}{ Species } & Withdrawal resistance of -- \\
\hline & No. 10 screws \\
\hline & Side \\
\hline & :Av, :ilax,:Min,:Av, :Wax.:Win。:Av, :Wax,:Min,:Av, :Wax. \\
\hline & D.: Lb.: Lb.: Lb.: ] \\
\hline & $:$ \\
\hline \multirow[t]{2}{*}{$\begin{array}{l}\text { Avodire ( } \mathrm{W} \text {. Africa) } \\
\text { Turraeanthus africana }\end{array}$} & $:$ : $488: 556:$ 424: $416:$ 476: $350:$ 560: 636: 496: 504: $574: 42$ \\
\hline & : \\
\hline \multirow[t]{2}{*}{$\begin{array}{l}\text { Nahogany, African } \\
\text { Khaya ivorensis }\end{array}$} & $:$ :568: 630: $484:$ 484: $552:$ 418: 666: $736:$ 590: $538: 616: 461$ \\
\hline & : \\
\hline \multirow[t]{2}{*}{$\begin{array}{l}\text { Mahogany, Colombian } \\
\text { Strietenia macrophylla }\end{array}$} & $: \begin{array}{r}: \\
:\end{array}$ \\
\hline & $::$ \\
\hline \multirow[t]{2}{*}{$\begin{array}{l}\text { Satirwood, Ceylon } \\
\text { Chlorophora swietenia }\end{array}$} & 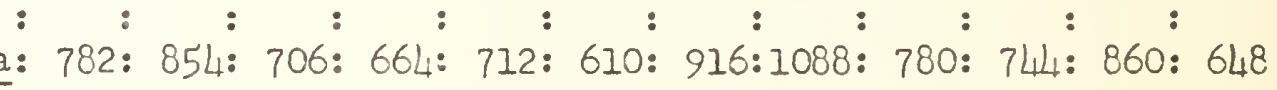 \\
\hline & : \\
\hline
\end{tabular}

Uses

The figured material is usually converted into veneer for use in decorative work, such as cabinet rork, paneling, interiors of railway coaches, ships' fittings (cabins on the Queen liary), and lighter types of furniture. The plain stock may go into lumber or ordinary plyrood and joinery. There is less demand for the rood as lumber because of the cross breaks and irregularities of growth ( $1,14,16,22,2 \underline{4})$.

Pulp from the light-colored avodire yields paper that compares well vith paper obtained from the ordinary commercial hardwoods (7).

\section{Supplies}

In the past, the Ivory Coast has been one of the main sources of log supply, especially of figured material, because logs are conveniently transported to seaports from this region. Overland transportation of logs has been poorly cieveloped. Lore recently, the Gold Coast has become another of the main sources of Iog supply ( $1,16,22)$. Avodiré is not available in large amounts, but logs were imported before rorld War II with average girths of 5 to 6 feet and lengths up to 15 feet (16). The logs first entered the French markets soon after Vorld Var I, and not until 1923 was much shipped into Geman markets. Several years later, it attracted notice in England and America (22). 
Growth rings.--The growth rines tend to be poorly defined, sometimes indicated only by a flattening of the fibers (6, $13,24,29)$.

Vessels.--The individual vessels are relutively small, oval to nearly round in cross section, and not distinct without magnification. They are numerous, evenly distributed, solitary or in radial groups of 2 to 4 vessels. The have simple perforations. The vessels frequently contain yellorish gum but no tyloses (17, 18, 22, 29).

Rays.--The rays are fine and often indistinct without magnification. Altrough the marginal cells are not markedly upriglit, the rays are ciassed as heteroreneous, mostly biseriate (occisionally 3 cells wide at the middle), and may be 6 to 25 but are generally 12 to 15 cells high. Low rays, rarely over 6 ceils high, are usually found to be uniseriate (18, 29). Ripple marks and guni ducts are absent (18, 29).

Parenchyma.--Parenchyma is sparingly developed about the vessels and may often contain calcium oxalate crystalo (18, 29).

Fibers.---Growth zones my be somerhat defined by rows of radially flattened fibers. The fibers are libriform and nonseptate "ith simple pits. They have relatively thin walls. Fiber dimensions are recorded as follows: length, I

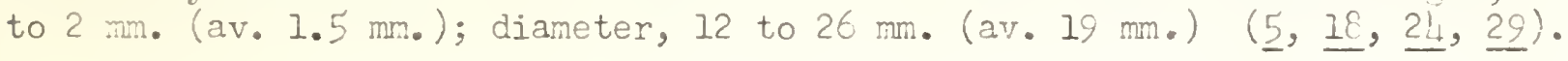

Wood Composition

Avodiré wood is composed of ash, 4.56 percent; fats and waxes, 0.80 rercent; cellulose, 62.15 percent; lignin, 32.49 percent ( .11 on a dry-leigtt basis). On digestion with $\mathrm{NaOH}$ in 5 percent concentrations for 8 hours uncer a rressure of 3 kilograms, avodiré gave a licht, bronish-yelio" pulp, which bleached easily and yielded 37 percent of bleacked pulp ( $\underline{5}, \underline{24})$. 
1. Anonymous.

1940. Avodiré (Turraeanthus africana). Wood (Brit.) 5(4):87-38, April.

2.

1930. Nos bojs Coloniaux (Côte d'Ivoire). Avodiré (Turraeanthus africana (Welw.) Pellegrin.) Assn. Colonies-Sciences et Comité Natl. des Bois Coloniaux, Paris; It pp.; 2 plates; 2 veneer samples.

(Rev. Tropical Woods $24: 48$ )

3.

1938. Gold Coast Timbers. Pub. in connection with the Gold Coast Exhibit at the Empire Pxhibition at Glascow, Scotland; 27 pp.;

II colored plates; 1 map.

4. Aubrèville, André

1930. Essai d'Identification des Meliaciees de la cóte d'ivoire. Reprinted from Acts et Comptes Rendus de I'Assn. ColoniesSciences (Paris) 57, 58, March, April, 15 pp。

5. Balsac, F. Heim de; Cercelet, G. S., and Balsac, R. Hein de

1925. Wood from the Ivory Coast. Bull. Agence Gen. Colonies 18, 520; Bull. Imp. Inst. 23, 482; (Cf. Chem. Abs. 20(8)1322, April 20, 1926)

6. Bergstrom, E.

1929. Avodiré (Turraeanthus africana). Natures Treasure Chest No. 3. Penrod, Jurden \& Clark Co., Cincinnati, Ohio.

7. Brush, W. D. and Sparhawk, W. N.

1943. West African Timbers for Use in North America. Unpublished material in U. S. Forest Service files. U. S. Dept. of hEriculture.

8. Cooper, G. Proctorl 4

1931. Unpublished Memorandum of Turraeanthus sp. in Liberia.

9. Engler, 1. and Prantl, K.

1889. Die naturlichen Pflanzenfamilien (Harms 1897) 3:4:294 and revised

1912. (1940) 19 b, I。; pp. 147-150.

10. Harrar, Ellwood S.

1941. Some Physical Properties of Hodern Cabinet Woods. I. Hardness. Tropical Woods 68:4, Yale Univ. School of Forestry, December 1.

11.

1942. Some Physical Properties of Modern Cabinet Woods. II. Screwholding Power. Tropical Woods 70:5, Yale Univ.. School of Forestry, June 1 .

EListed in Record's bibliography (29). 
1942. Some Physical Propertins of hodern Cabinet Woods. III. Directional and Volune Shinkare. Tropical Woods 71:27, Yalo Univ. School of Forestry, Septeriber 1.

13. Hedin, Loujs 4

1930. Etude sur la forôt et les bois du Cameroun sous landat francais. Paris, pp. 88, 96-97.

Il. Howaru, A. L.

1948. Timbers of the World. liacmillan and Co., Ltd., London. 3rd edition, pp. 50-51.

15. Hutchinson, J. \& Dalziel, J. M.4

1928. Flora of West Tropical Africa. Vol. 1, Pt. 2, np. 495-496.

16. Jay, B. A.

1950. Timbers of West Africa. Timbor Development Assoc. Ltu., 75 Cannon St., London E.C.L, pp. 20-21.

17. Kribs, David A.

1930. Comparative Anatomy of the Woods of the lifeliaceae. Amer. Jour. of Botany 17:8:724-738, October.

18. Kribs, David A.

1950. Commercial Foreign Woods on the American Harket. Edward Bros., Ann Arbor, ilich., p. 116.

19. Lamb, George N.

1947. Foreign Woods, Origin, Use, Pronerties, and Iomenclature. Wood Products 52(12):25, December.

20. Nansell, R.

19L8. Avodiré. Turraeanthus africanus Pellegr. (Lieliaceae). Furniture i.ifg. February 1943, pp. 28, 34.

21. Martineau,

1930. Etude sur les temperament des principales essences de la cáue d'Ivoire. Actes et Comptes Rendus de I'association ColoniesSciences (Paris) 6:56:30-35, February.

22. Nell, C. D.

1929. Avodiré, One of the Newer, Firie Imported Woods. Veneers, Vol. XXIII, No. 9, p. 17 .

23. Neniaud, J. and Bretonnet, F.L

1926. Les Bois Coloniaux d'Afrique dans I'Industrie. Melun, pp. 31,-35.

24. Nieyer, Hans

1928. Avodiré, ein Nutholz Westafrikas. Tropenpflanzer 31(1):15-16, January. 
25. Neyer, Hans

1933. Book of Wood Names. (Buch der Holznamen) N. \& H. Schaefer, Hanover, Germany.

26. Monnin, M. M. et Collardet, J.

1930. Etude Physique et iécanique des Bois Coloniaux, p. 90, table III. Asso. Colonies-Sciences et Com. Natl. de Bois Coloniaux, 60, Rue Taitbout, Paris, France.

27. Normand, D.

1943. La denomination officielle des principaux bois coloniaux francaise. Re. Bot. App. et d'Agr. Tropical 23:260, 261, 262: 160-16/.

28. Pearson, C. H. and Son Hardwood Co., Inc. 4

1930. Avodire. Leaflet. New York.

29. Record, S. J.

1931. West African Avodiré, (Turraeanthus africana). Tropical Woods 26:1, Yale University School of Forestry, June.

30. Roddis Plywood Corporation

1950. Characteristics of Modern Voods. 3rd edition, p. 5.

31. Schmidt, Von Eberhard

1950. Avodirê, Weltholzwirtschaft (4): Beilage Nir, 16, A.pril, I colored plate。

32. Vigne, C. 4

1931. Memorandum on "Turaeanthus spp. in the Gold Coast."

\section{Additional Reference}

Lebacq, L. and Istas, J. R.

1950. Les Bois des Meliacées. Annales du vusée du Congo Belgo Tervuren (Belgique) Série in $8^{\circ}$ Vol. 2, illus. (See pp. 55-59, analysis). 